\title{
Employability, Empowerment and Employers, Between Debunking and Appreciating Action. Nine Cases from the ICT Sector
}

\author{
Hans Pruijt 2012
}

Paper submitted for publication in International Journal of Human Resource Management

(Pruijt, H. (2013) Employability, Empowerment and Employers, Between Debunking and Appreciating Action. Nine Cases from the ICT Sector. International Journal of Human

Resource Management, 24(8), 1613-1628,

http://dx.doi.org/10.1080/09585192.2012.725083 )

\section{Abstract.}

An important strand in the literature promotes the idea that investment in employability, specifically in marketable skills and talents, self-presentation efficacy, actual levels of skill, knowledge and experience, will go a long way in addressing the problems caused by creative destruction. The paper examines employability policy and employees' perceptions of their employability in nine information and communication technologies (ICT) companies, located in Germany and in the Netherlands. In all these companies, sustained employability was problematic. Together, they form a critical case for testing some of the assumptions of employability thinking. Beyond this, the paper explores the space for action. Some of the companies pioneered sophisticated, high organizational involvement forms of employability enhancement, while others highlighted the interplay of employability and employee protection as a mechanism that can help create security.

In 1951, C. W. Mills (58-59) wrote: "To be free and to be secure is to have an effective control over that upon which one is dependent: the job within the centralized enterprise". A key problem of our time is if and how employees can be free and secure by having an effective control over their employability. The aim for this paper is to contribute to the debate about this by focusing on the ICT sector, because it is characterized by rapid change which makes it a prototype for an employability-dependent careers pattern, and within this sector on companies whose management takes a keen interest in employability.

The research question is: what are the implications of the new psychological contract based pursuit of employability by ICT companies? The paper starts with some conceptual clarification regarding employability and the new psychological contract, followed by a brief review of theoretical constraints. Then it outlines the employability-related challenges that work in the ICT field entails, and positions the nine companies studied as fairly exceptional, 
critical cases in terms of the interest shown in the issue of employability. In the empirical part of the paper implications and constraints are explored on the basis of 37 interviews with employees and managers in the companies.

\section{Conceptual clarification}

Currently, the central idea concerning security in working life is that this is a matter of investing in employability (Arthur and Rousseau 1995; Guest 1998; Ellig 1998; Heckscher 1995; Kanter 1989; 1993; 1995; Littleton and Arthur 2000; Yerkes 2011). Employability can be defined as empowerment in matters of career development. This definition follows Gazier (2001: 23), who concludes after surveying the various meanings given to the term employability that the most up-to-date definition is what makes "each worker a more aware and a more independent organizer of the succession of activities and commitments that, combined, constitute his/her working life". It is also consistent with Schmid's (2006) point that autonomy is an important component of employability.

The concept of employability has a strong normative content. It figures in a discourse that can be seen as inducing people to feel individually responsible for macro-economic problems (Jacobsson 2004). In this paper, however, employability is primarily seen as central concept in a theory about careers. This theory can be outlined as a set of four propositions:

1 Because of rapid economic and technological change, job security is becoming more and more unlikely; employers cannot realistically promise it to their employees (Kanter 1991; Ghoshal et al. 1999: 15; Herriot and Pemberton 1996).

2 With the disappearance of job security, employees can derive security only from their employability (Kanter 1989).

3 Employability of employees is amenable to substantial enhancement by investing in it (Kanter 1993). Various forms of investment are possible. The primary one, at least according to EU and OECD recommendations, is training aimed to increase professional knowledge and skills (Jacobsson 2004). Other forms of investment can aim at gaining experience in new contexts, increasing awareness of marketable skills and talents, boosting self-presentation efficacy (Ghoshal et al., 1999) and expanding the employees' network of contacts (Arthur 1995). Kanter (1993) suggests that acquiring an entrepreneurial attitude is important. Arthur (1995) and Littleton (2000) imply that adopting a lifestyle based on systematically chasing learning opportunities and viewing employers as contingent, in other words pursuing a "boundaryless career", also enhances employability.

4 Investment in employability, especially in the shape of training, can exist as a joint responsibility of companies and employees (Jacobsson 2004). The idea is that employers have an interest in this because of the emergence of the "new psychological contract". A psychological contract is a set of expectations that the employer and employee have of each other. The theory is that the "old psychological contract" in which the employer was expected to try and maintain a permanent employment relation with the employee in 
exchange for loyalty and performance is giving way to a new psychological contract where the above no longer holds. In the new psychological contract, the employee expects that the employer will invest in her or his employability. In return, the employer expects commitment (Ellig 1998). Beyond boosting employee commitment, other possible reasons for companies to invest in their employees' employability are to establish a reputation as an attractive potential employer (Ghoshal et al. 1999) or to make layoffs easier (Tamkin and Hillage 1999).

Apart from paying for training and facilitating it, Baruch (2003) lists other activities that employers can undertake to enhance the employability of their workers: organizing informal learning and job rotation, supporting temporary placement in other organizations, providing information about job opportunities inside and outside the organization, supporting active searching for job opportunities in the organization's network, and helping employees to become more aware of what they can do and want to do through benchmarking, testing, counseling and self-assessment.

\section{Theoretical constraints}

The four propositions outlined above seem consistent, but how realistic is the idea that employability security can be created? There are several theoretical reasons for having some doubts about this. One of these is that employer-paid training presents a classic collective action problem. While most employers will see the value in a well-trained, up-to date and potential-maximizing workforce in the economy, investing in it is not directly in the interest of individual employers. It is rational to poach staff from competitors that invested in training (Crouch 2006).

When we consider investment in employability, the role of the employee should not be overlooked. The employee has to invest too, at least energy, and often time. A theoretical constraint that applies here is that turbulent conditions create uncertainty about which direction to choose. Crouch (2006) suggests that investing in a given skill or body of knowledge is a gamble, because it is impossible to gauge beforehand whether it will be of any use. Managers who are adamant about employability tend to be able to make only vague statements about what exactly employees should learn (Hallier 2009). Hirsch and Shanley (1995) remind us that a traditional careers system offers focus, coordination, and a reduction of uncertainty that helps employees invest effectively in themselves. In a system of boundaryless careers this is all gone. If Hirsch and Shanley are right, we should expect that employees will feel somewhat paralyzed as a result of the uncertainty about possible career paths.

A further constraint involves a clash between producing in an efficient way and learning. Svensson (2004) indicates there is a contradiction between a production and a learning logic. He refers to an extreme case of Taylorist production that does not offer space to reflect, experiment, make mistakes and think differently, but we can infer that the contradiction exists whenever routine is part of money-making activities. 
External pressures on the organization can lead to financial constraints that make lasting bargains between employer and employees, i.e. win-win situations such as the new psychological contract based pursuit of employablity, unrealistic. Such pressure can be the result of coordination between firms, which often takes the shape of "extended hierarchies" (Thompson (2003). In a company that occupies a subordinate position in a value chain, its top management can face imposed speed-ups and systemic rationalization. Also, a company can face pressure to meet short-term financial demands when it ends up in the position of being an asset that is bought and sold. Such mechanisms can limit the capability of employers to "keep their side of the bargain" (Thompson 2003: 359).

Finally, we have to take into account labor market driven erosion of employability as a mechanism that can prevent investments in employability to bear fruit. This involves addressing the qualitative supply side bias that employability theory commonly shows (McQuaid and Lindsay 2005: 204-205; Jacobsson 2004). This bias entails an implicit assumption that investments in skills, knowledge, insights and contacts can, for example, offset counteracting characteristics of the demand for labor, such as age discrimination. Erosion of employability can also ensue when cheaper workers with comparable skills enter the game, for example because of the offshoring of jobs (Castells 2000).

In the empirical part of the paper, these constraints provide structure to the analysis.

ICT sector as the prototype of employability dependence

The ICT sector is often presented as the model for careers based on employability (Kanter 1995). In fact, the "roving engineers" who created Silicon Valley were the sources of inspiration for the idea of employability security (Kanter 1989). The same people served as prototypes for Littleton's (2000) "boundaryless" careers. Smith (2010: 295) counts ICT workers, together with for example investment bankers, among those for whom "maintaining employability is part and parcel of their occupational culture."

The ICT sector field presents clear challenges in terms of maintaining employability. Unfilled vacancies for, and unemployment of, software developers exist side-by-side. Companies are hiring and firing simultaneously (Meares and Sargent 1999; Schouten 2006). This points to problems in the areas of internal mobility and work-to-work transitions. After analyzing 71 qualitative interviews with ICT workers in small and medium sized Australian companies, Brooke (2009: 244) summarized: "Many respondents perceived that their careers would be short, and projections of prolongation into their fifties and beyond were rarely articulated" and "many of the older workers were finding it difficult to prolong their careers" (Brooke 2009: 246).

The challenge for ICT workers to maintain employability may well be increasing, as Cappelli (2001) notes that hiring the right skills at the right moment, i.e. "buy" instead of "make", has become more important. Consultants or contractors especially are expected to "hit the ground running" (Barley and Kunda 2004: 177). Moreover, the rise of outsourcing, offshoring and the use of flexible workers supplied by temporary work agencies after 2000 made lifelong learning of employers less of a priority for managers (Van Velzen 2004: 157). 
The literature on the ICT sector shows that the theoretical constraints in the new psychological contract based pursuit of employability are indeed present. The collective action constraint is evident in the research of Van Velzen (2004) and Bakker (2006) who note that at least some ICT employers made use of training as a means to retain valued employees, which indicates that the new psychological contract seems to be effective to some extent, but also report that companies often used payback clauses that applied when employees left within, for example, two years of the training. Payback clauses prevent companies from paying for the collective good without deriving a private benefit from the investment, but it seems logical to expect that payback clauses hamper training.

Barley and Kunda's (2004) ethnographic study of American ICT consultants illustrates how uncertainty about future developments presents a problem for ICT workers. The study shows that these workers were concerned about the risk of making a bad bet when deciding whether to invest in learning a new technology.

The literature on the ICT sector also hints at a labor market driven erosion of employability. Many jobs in the ICT industry demand not just up-to-date knowledge and skill, but also the ability and willingness to put in long hours and to put up with stress (Latniak and Gerlmaier 2004; Longenecker, Schaffer et al. 1999). A further factor that affects employability in the ICT sector is quickly changing demands in terms of new skills that are not cumulative (Cappelli 2001). The employability of ICT workers is also affected by the perception that there is an age for employees of peak performance, which typically lies decades before the official retirement age (Brooke 2009). Another relevant perception is that suitability for working with a given technology is related to the generation to which someone belongs, generation being defined by the technology that was current during the person's formative years (McMullin, Comeau and Jovic 2007). Van Velzen (2004) reports that in the Netherlands older ICT workers are less wanted and receive less training opportunities.

\section{Data and analysis}

The data on which this paper is based consist of verbatim transcripts of 37 interviews with individuals working in ICT companies in Germany and the Netherlands. These interviews were made in 2005 as part of the Workforce Ageing in the New Economy (WANE) study of information technology employment. 'The purpose of this study was to investigate from a life course perspective ramifications of changing labor markets. The interviews represent four German and five Dutch companies. Case characteristics are in Table 1. 


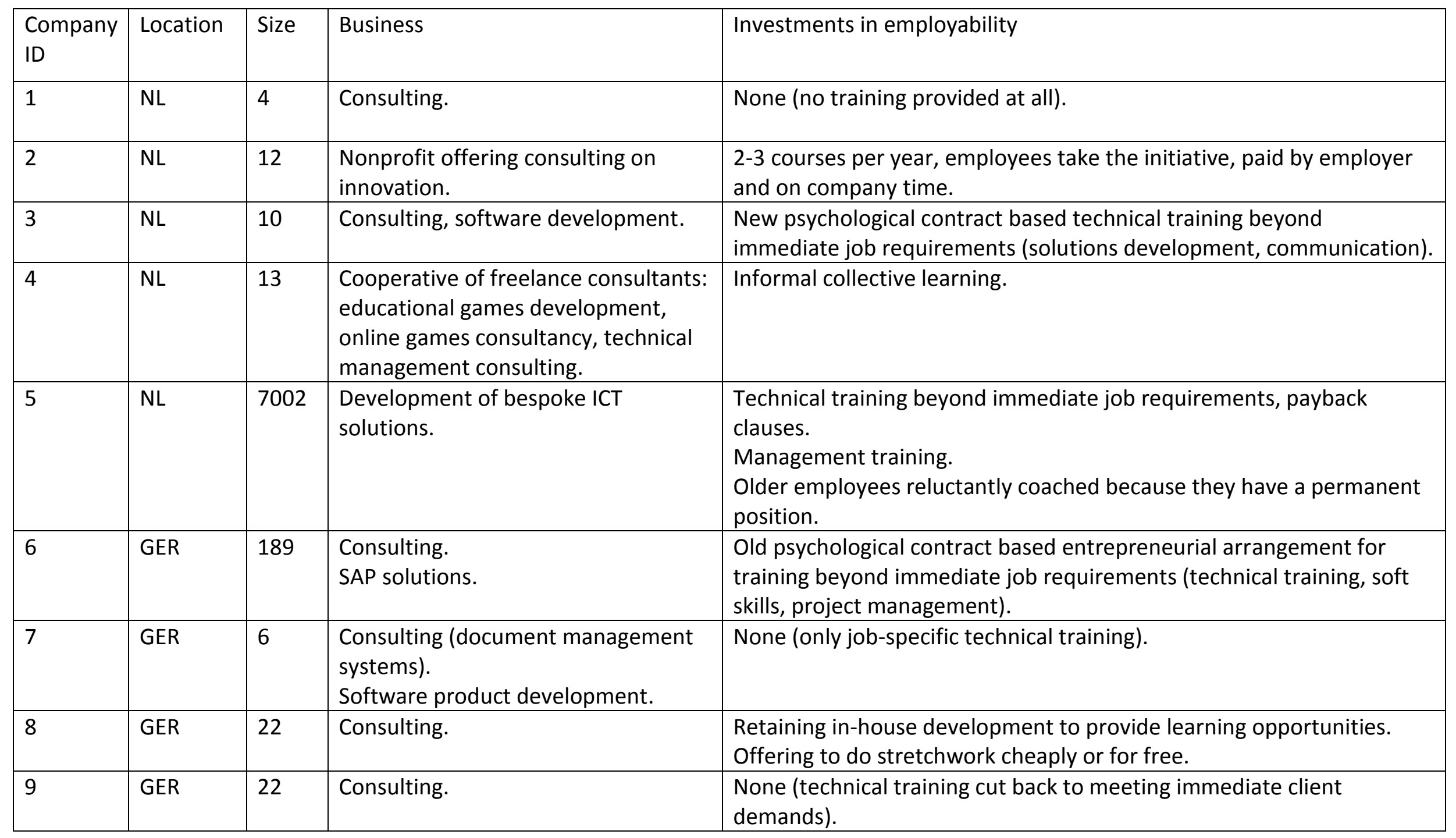

Table 1 Case characteristics 
The sample is biased in a way that is advantageous to the purpose of the paper, because it seems plausible that it over-represents companies in which the managers take a keen interest in the issue of employability. This is due to the fact that the strategy for recruiting companies to be studied involved publishing articles about the project in the trade press. These articles prompted managers in several companies to approach the research team to have their organizations included in the study.

That these cases are fairly exceptional become apparent after examining existing research. Scholarios et al. (2008) show that only a minority of small and medium sized ICT companies try a proactive approach to enhance the employability of their workers, while in most companies employability policy tends to be only ad hoc. Augustsson and Sandberg (2004) report that many Swedish interactive media companies did not have a consistent employability strategy. Marks and Scholarios (2008) studied two ICT companies in transition, in which social skills were gaining importance because of increasing interaction with clients. They note that even when managers were quite aware of the fact that the skill requirements for the work were changing, they nonetheless showed little initiative to increase their workers' abilities to comply with the new demands. Marks and Huzzard (2010) report that in their sample of four Scottish software companies, the employees tended to attach greater importance to job security than to learning new skills. Augustsson and Sandberg (2004) show in their study of the Swedish interactive media business that employees deemed on the job learning more important than training, while on the job learning tended to remain limited to finding out how to solve the concrete problems that cropped up during work. Augustsson and Sandberg acknowledge that this may contribute to employability, but that this depends on the nature of the problems at hand and on how wide the search for solutions is. They also note that employees only used part of the time which their employers had made available for competence development. In this paper we are dealing with the minority of ICT companies that are comparatively employability-aware.

The average age of the 37 respondents was 41 . The youngest respondent was 20 years old, the oldest 73. 12 respondents, or 32 per cent, were women. Among the respondents were managing directors, IT managers, consultants, software engineers and sales and marketing people.

Interviews, conducted in English, were semi-structured. Respondents were asked to reconstruct their careers, and explain events and decisions, and to reflect about the future, especially about the question whether they would be able to continue working in ICT until the age of sixty-five. Managers freely explored the management aspects of the issue. Basically, only interview fragments that related to employability were coded. Open coding was performed and short analytical memos attached to some of the codes. Analysis was performed using the program InterviewStreamliner (Pruijt 2012).

The new psychological contract and the collective action problem

Across the board, the interviewees indicated that it was essential that ICT workers continuously invest in their professional development. Offering opportunities for skills development emerged as a key role that organizations were expected to play. A textbook 
example of the new psychological contract comes across in the following explanation by a managing director of Company 3:

"For us it's very important that we develop employee skills and in the kind of technical profession he wants to be in. I mean for me it's because we're a very small company I can say to one of the technical consultants, 'I want you to develop more in web-based solutions'. But if he doesn't like it, he will not do it, so what we ask them is 'What kind of way you want to go, do you want to go to web development, do you want to go to document development, do you want to go to other developments?' That's the main thing we do and then from there we look to more education and training. [..] the overall company must have specialists in all those types of businesses. But I find it very important and I have all the people who were hired the last few years [..] still working for us [..] I don't think they want to leave at short notice, because, yeah, well they're happy because they can develop their own way. I mean their development is also the company's development because if you are so small the most value is by employees."

In the quotation above, the new psychological contract appears as a solution to the collective action problem; employees are expected to be loyal in response to the opportunities for development that the company provides.

In Company 6, the expectation is not so much that employees are loyal, but that they show entrepreneurial engagement. Company 6 offers an opportunity to see in action that what Scholarios et al. (2008: 1039) suggest as a theoretical possibility: entrepreneurship as a component of the psychological contract.

In its mission statement, Company 6 proclaimed: "Our employees' entrepreneurial initiative takes centre stage. We demand that they be willing to take responsibility and to develop their abilities. We support them in their progress and offer them the freedom to be creative." In this company, entrepreneurship was seen as a continuum; at the highest level there was the possibility for employees to turn a business idea into a separate company under the umbrella of the holding company. The concrete example of this was an initiative by a consultant to create a division that targeted the HRM market. The minimum level of entrepreneurship that should hold for every employee was defined, in the words of a manager as:

"Being autonomous within their role, and being in charge of [..] their working place. [..] We want everybody to be sensitive towards how long will my project last, when do I need the next project, to be proactive about all this, and not just being dragged along with us. [..] What we want to achieve is that people working with us have a direct feeling of their particular workplace, of their particular project, how safe it is really for them, and what they have to do in order to make it a sustainable workplace. [..] each and every consultant in our company has to move along in order to have a safe working place. They have to take risks even, some kind of entrepreneurial risk, they have to invest their time into learning new technologies, learning new business, making them familiar with new business processes, industry competencies." 
Not all employees were enthusiastic about this idea, one interviewee called it "new wine in old bottles" and the manager quoted above acknowledged that "some technical experts just maintain the position "we are not sales people'". Nevertheless, the vision was institutionalized in the organization. At least one consultant among the interviewees was thinking about creating a new business within the company.

As mentioned above, the new psychological contract can be seen as a solution to the collective action problem. Nevertheless, its power is limited, as is evidenced by the use of payback clauses. In the large company in this study (Company 5) management was receptive to the employees' wishes regarding training, but the company rule was that the employee had to stay on for three years or else had to repay the cost. Training costs were written off in three years. An interviewee said that this caused some frustration and discouragement, but that there was some leeway for bargaining.

When a private good for the employer, in the shape of skills that the organization itself needs, is added to the collective good of a highly employable workforce, investing in training because more attractive. Another employee of Company 5 explained that it was helpful to make a case for a win-win situation when asking for training and gave an example of how a proposal for training could be framed:

"Well, this is a very important way of educating myself because it's for myself, okay, but it's also good for the company, I see the development of this and so on and so on."

Other companies used the incentive of allocating company time for training to induce employees to focus on skills that the company needed, while still paying for the cost of all training regardless of its direct use for the company. Also managers made suggestions for training, and discussed possible new opportunities with consultants in business development seminars. Such activities respond to employee uncertainty about future developments, while simultaneously aligning training outlays with organizational needs and thereby reducing the collective action problem.

\section{Addressing the clash between a production and a learning logic}

In ICT, the combination of high workloads and the rapid succession of new tools creates a clash between a production and a learning logic. A 47 year old ICT professional, working in a large company in the Netherlands (company 5), explained:

"Things are changing constantly and well, until now I never found that a big problem, I was quite interested in things, new things [..]. I used to think that was not a problem. As I am getting older now I have some more trouble in keeping up to speed [..].The workload is getting higher so you can't do things during your work any more. I used to have possibilities to look up things, read something during working hours and now the workload has increased and that has become more and more difficult and then you have to transfer to your private time and so that conflicts of course with family life, but family life is not the cause of it. Perhaps if you were not married 
and you didn't have a family life then you perhaps have time to study all these things. [..] I'd rather go sailing than finding out about the next thing that Microsoft has invented."

A way to manage this clash was explored in Company 6. Company 6 had an innovative wage system that presented employees with the choice between, on the one hand, generating cash by exploiting their existing knowledge and, on the other hand, investing in learning. The key part was a basic income for consultants when they were not working on a project for a client. This basic income was relatively low, 56 percent of the amount excluding bonus that a consultant would get when working on a client project. It offered the opportunity to invest in learning or business development and it was a way to mobilize the employees to create employability security on the company level. As a manager put it:

"In a sense they pay for their freedom when they don't get a customer project. So their income is substantially lower. [..] However, it's very clear this fixed income is not compatible to typical incomes in the market, it's substantially less than you earn as a consultant when you produce in a different company, and when you produce more billable hours on the company. [..] Everybody, in order to stay with us, every employee needs the feeling that he or she made their own right choice between, how much time do I invest, and how much time do I use to optimize my own income?"

One of the consultants described this balancing process:

"It should be very good to learn a new programming language but the time I spend to learn it, I cannot make any single incentives, so it is a loss of money for me. Although then when I learn it the costs for all the schooling is paid by the company, but I cannot earn any money beyond my base salary during that time."

Financial constraints and ways to work around these

In the varying extents to which companies were investing in skills development we can discern a kind of scale. Of the companies mentioned above in this section, we can say that they invested in training beyond immediate organizational needs, thus clearly in their employees' employability, and thereby represent the high end of the scale.

Further down the scale, there were companies that basically catered for their own direct skill needs but not more. There was training, which perhaps had an effect on employability, but this was not the goal. Some companies, that had previously offered generous training, slid down the scale to land in this position. An employee of a firm (Company 9) that used to have a broader training policy, but that was cut back by management, explained that the current policy was to:

"Provide training only in situations when there is a concrete demand. So, for example, let's assume I have to see this or that client and the client expects this or that know-how, which I don't have to a certain degree [..], then there will be further training provided." 
She indicated that she respected the management 's decision to cut back on training beyond actual job requirements and suggested that the damage to employability was limited:

"And I have often noticed for myself that training is not effective unless you get a chance to really use your knowledge afterwards."

What may explain this sliding down the scale, is that this company was in a subservient role to its customers. One of the consultants described the experience of working for a client company as follows:

"We are coming from outside. We are not part of the client's company but part of the consultant agency, and we are on loan, commissioned as specialists and, yeah, it's always some kind of a difficult relationship, [..] or, well, not always, but it is very easy for the internal workers too, and there are things like a better salary, so we sometimes feel exploited because they can do with us what they want."

This can be seen as a case in which an extended hierarchy prevents an employer from keeping his side of the bargain (Thompson 2003).

Even further down the scale we find companies that did not invest in skills development, but instead completely relied on the "buy" option. Financial and time constraints, not lack of interest in employability, were the cause. According to the managing director of Company 1 , his company was too small to have the possibility to train. New people in the team had to be "billable" immediately. Here, the shift from "make" to "buy" appears as a two step process. The client's decision to hire consultants instead of giving the job to inside employees is the first step. The second step is for the company that supplies consultants to rely on the "buy" option too.

Various companies explored ways to work around financial constraints when creating opportunities for learning. Company 6's innovative wage system made it possible to combine a decline of business with an increase in training. Because employees in training earned much less than when working for a client, there was "a way of reducing load without having to set people free" (managing director).

Saving training expenses by engaging in informal learning was an important strategy too. Especially when it took place collectively it was a reason for enthusiasm. A consultant (Company 6) illustrated this nicely when he told how he had learned to customize the enterprise resource management system SAP:

"[..] my colleagues know much about SAP so I learn from them. We're sitting together and talk about this and this, how do you do this [...]. So I know something, they know something and we're sitting together and discuss about something and try it out."

Of one of the other companies (Company 2), one might even say that organizing informal learning was the reason for its existence. This company was a cooperative consisting of ten freelance consultants, who had set it up to promote collective learning and networking. 
There were substitutes sought for professional training courses. In-house specialists sometimes attempted to train their colleagues. Several of the companies organized seminars, in which employees or people from the organization's external network presented. In contrast to collective self-learning, these initiatives tended to get a mixed reception.

Another way to acquire new skills is what consultants in the US have called "stretchwork", that is work that is close enough to their area of expertise to be doable, but sufficiently remote from it to provide an opportunity to learn (Barley and Kunda 2004: 260). A consultant of Company 9 deemed this an increasingly remote possibility:

"I always think it is understandable from the point of view of the client, but eventually it is like a dead end: I always get my project assignments on the basis of the knowledge I have. This has always been a problem for me, that I keep repeating the same thing. It's understandable. You get the project in an area which you are best in. But you hardly ever get to learn new things that way. It would be nice but probably impossible in practice. It would not work time-wise, you would have to find the right people, the design of the projects must be appropriate and so on. But taking one step out of line at a time, so to speak, in order to get a bit of a different perspective [..]. That is however not what the client would experience as optimal. They, of course, prefer to have someone who can cover with his or her know-how all the [..] demand. [..]

Company 8 has a deliberate policy of investing in stretchwork, but it needs the clients to play along:

"We often offer to our clients: look, we have a colleague here who is appropriate, in theory. Though this person lacks the special experience that the client demanded. So we offer to work for a certain time at a very low hourly rate, or even for free. An orientation phase. Thus you get the chance to get familiar with unknown areas. Admittedly, this has become more difficult over the last two years. But it still happens." (engineer Company 8)

Several of the companies struggled to get away from the precarious position of being just a labor pool for other companies. When Company 8 started in 1984, all its employees worked as consultants with clients. Then, in the 1990s a small group started to develop a travel scheduling system. This was a successful product and eventually all developers worked inhouse on it. Suddenly, in 2001, 70 per cent of the revenue from the product disappeared:

"In order to survive we started again with let me use a very ugly term "body-leasing" activities. This is actually very ugly." (manager Company 8)

However, because switching to pure consulting would rob the consultants of the opportunity to learn quality management and project management, the firm's management made the deliberate decision to retain internal development:

"But we do not want to give up internal development, for the client as well as for our own purposes. Because this is the only chance you have to give people [..] further 
qualifications. To train them in quality management; to teach them standards and norms, or things like that. After all, you don't learn everything there is to know during you academic education. In fact, I could put it quite differently: your job training actually starts only after your academic education. [..] In our business everyone should know how to manage a project. Otherwise they will never be able to advise a client, if all they do is work on narrow-gauged filling in for someone else, that doesn't work." (manager Company 8)

It is clear in this case that it is important for a company to have a product in addition to offering consulting. Purely offering consultants constitutes the bottom of the pecking order, providing not just labor, but solutions, was seen as much more desirable.

\section{Labor market driven erosion of employability}

Some of the consultants were pessimistic about the long term prospect for their employability. A reason to take their assessment seriously is that consultants get regular feedback about their employability because their managers offer them to clients, sometimes together with one or two colleagues to allow the client a choice. Clients decide whether a particular consultant would be the right person to assign the project to. When consultants voiced pessimism about their employability, this tended not to be linked to a lack of training or learning opportunities, but to factors on the demand side: demands to work long hours, to be current in ever-changing technology, and a youth bias in the demand. Exceedingly rare among respondents was the opinion that a sustainable technical career was just a matter of keeping developing oneself. The most outspoken representative of this view was a 28-year old programmer. Others were downright negative because of the combination of stress, working long hours and the need to constantly update knowledge. A 37 year old worker complained that he had difficulty to get on, having to compete with 26 year olds, and that continuing working long hours would eventually lead to a burnout. A German engineer (Company 8) explained how he did not get an assignment with a client because he could not meet the demand of working 60 hours per week:

"About six months ago, we got a request from a client. And we had some talks.[..], and they demanded that I accept working 60 hours a week. I said, I cannot guarantee this [..]. So, that was clearly the exclusion criteria. The fact that I honestly told them, "Look, I will happily give it a go, but I cannot make any promises".

The engineer added that this job would likely go to a freelancer. This engineer more or less drew a line in the sand against the demand to work long hours.

Repondents brought forward several ideas about how the problem of the combination of stress, working long hours and the need to constantly update knowledge could be dealt with, such as working shorter hours, or being allowed to work no more than 40 hours. A typical idea, at least for those who thought that a long career in ICT was possible in principle, was that moving into management would help. Also design work was thought to be less susceptible to skill obsolescence than implementation. One respondent added that at some point in the career, a change in job content from implementation to transmitting 
knowledge should be made. There were, however, no indications of concrete steps taken to make any of these ideas a reality, nor of any expectation that employers should make efforts in this direction. The only thing that came close was a strategy to focus on a niche in which there was little competition. For example, one respondent felt secure, because his specialty, information architecture, was rare. However, a niche can be at risk. A consultant (Company 9) derived an uneasy sense of security from his knowledge of an old computer system (designated "the host"):

"I see a risk, very clearly. I may have my hopes that I will just about slip through [..]. I have the knowledge of the host [computer], and for the time being the hosts are still needed. But as soon as the major companies will turn their backs to this, I might be faced with problems, that may be. Simply for the reason that you don't get hired anymore when you have lost your job. I see that with some of my colleagues. Especially if you are over 50 , chances are absolutely grim for getting new employment. You can always get lucky, I wouldn't deny that, but in my case it will be crucial whether the host is still running."

Thus, we see no components being added to the psychological contract that entail a protection against the erosion of employability by the combination of stress and working long hours. This was different in regard to another mechanism that causes an erosion of employability: a youth bias in the demand for labor. In ICT, the demand tends to concentrate on workers who are relatively young. In part this youth bias may be a matter of unfounded perceptions among clients. But a 73 year old managing director (Company 8), who was appalled by age discrimination, observed that:

"if a group or an individual is called to a client, either as consultant or as project director or simply to offer support for some project then it is usually the younger ones who tend to be the favorable choice, who quickly and very easily go and download whatever tools from the internet and know how to click it all together. Why, this is some kind of art actually, I don't really want to neglect this. And my experience has been that many young employees are about three times as fast as the older ones in developing a new program".

However, she added that the young consultants lack the experience that is needed to ask the right questions.

An engineer told of a company in which she had previously worked, that, after she had left them, closed their doors "pro forma". After a while it was founded again and everybody below forty was hired again.

Older workers tend to be tolerated rather than wanted. Consultants who are rented out to clients face a constant series of hiring decisions. Typically, the client wants to have a choice. A managing director (Company 9) explained:

"At normal times you have a handful, or sometimes a couple more, at your disposal. You get a project commission with a list of characteristics, of the know-how the employee is supposed to bring into the project, and then you can choose between a very limited number of people. And the client looks at it, looks at the know-how, and 
then selects someone. It's not as if our directing management was able to make the selection. So, it is only logical that they choose the person who matches their profile best. But it's a shame, sometimes."

Older consultants often lose out:

"If you talk about older employees, the thing is that we get to hear remarks with regard to commissions, even emails, when we send out people above fifty, suggesting that we had seemingly offered our latest Volkssturm" [German militia at the end of WWII, known for the large number of old men that served in it] (managing director Company 8)

She described how older employees are trapped in a "Catch-22 situation". Clients expect an older consultant to have achieved a lot already and to be very high in the hierarchy, and therefore expensive. For this reason the older consultant is not likely to get the job. Or, when the older consultant is offered at a low rate, the client might think "he has not achieved anything in all this time" and decide against taking the consultant. There is a cultural element present as well, when counterparts on the client side are much younger:

"if you look at the employee level, the very IT company's employee who needs support, for whom we are supposed to build something, or who is supposed to give approval to our project, has a completely different language code. I would almost say it is a linguistic problem. This may sound a bit grand now. But these young people are playing ping-pong with a certain terminology" (managing director Company 8)

This managing director added that when the services of an older consultant are offered at a low hourly rate, a typical reaction is "we won't take him on to our project with these low rates, because all our staff is very young and we believe that this could become difficult."

Some employers felt a moral obligation to protect older employees. An example: Company 8 was a family owned business. The owners were looking for a buyer because there was no successor in the family, while the managing director was already 73 years old. A prospective buyer insisted that all employees over 50 should be dismissed, which the owners declined, referring to their social responsibility and the personal relationship they had developed with people with whom they worked for 18 or 20 years and the know-how that they had.

After making it clear that his company (Company 5) would never hire older programmers, an information architect turned to a concrete case of an older programmer already employed by the company:

"But if somebody is in yeah we have to try to manage him through the new job and have him escorted on the job."

There were several courses of action in evidence to address the youth bias in the demand. A partial solution involved sending consultants to clients in mixed age pairs. Another one entailed assigning older employees to internal projects. Not all companies had such these projects, however. Some did consulting only. 
For a correct interpretation it is important to realize in the Netherlands and in Germany, there is legal protection against dismissals: the moral obligation to protect employees is undergirded by a social and legal norm (Pruijt and Dérogée 2010).

\section{Concluding notes}

This paper assesses the implications of the new psychological contract based pursuit of employability by employability-aware ICT companies. The ideal of a highly employable workforce is characterized by a collective action problem: employers who invest in the employability of their employees may be helping them to move to competitors. The new psychological contract appeared as a partial solution to this collective action problem, because investing in employability makes an employer attractive. That this is a partial solution is evidenced by the use of payback clauses.

When managers direct the professional development of their employees, they are helping to provide a private good for the company, in the shape of skills that are of direct use to the company, thereby alleviating the collective action problem. Simultaneously, they also cater to the employees' need for a structure that guides them through an uncertain future.

A clash between a production and a learning logic presents an obstacle. It does not seem possible to eliminate it, but one of the companies pioneered an exceptional, innovative way to manage it. This was done by offering employees a choice between exploiting existing knowledge when working on lucrative client assignments, or exploring new areas of knowledge at a low base salary. Simultaneously, this strategy liberated the consultants from the stigma of temporarily not having a client assignment.

Some of the companies that did not, or no longer, invest in training for employability, or in some cases in training at all, occupied precarious positions as suppliers of flexible labor caught in a trend for skills to be increasingly bought rather than developed. These companies expressed the new psychological contract based pursuit of employability in the form of strategies that compensate for a lack of resources for training. Some of these informal alternatives were rewarding to the extent that the employees did not experience lack of training as a breach of the psychological contract.

Factors that operate on de demand side erode employability. Two of these, the demand for putting in long hours and coping with stress causes prompted various ideas among the consultants, but none of these seemed to be incorporated in the psychological contract. In contrast, the youth bias in the demand for ICT consultants' services, a second factor that causes erosion of employability, was subject to interventions. Managers felt that they had to do something against it. Therefore, we can say that in some of the companies, efforts to protect employees against demand-side driven erosion of employability were part of the psychological contract. Such protective efforts entail a concern for job security, which according to employability theory should be antithetical to a psychological contract that emphasizes learning (Arthur and Rousseau 1995; Guest 1998; Ellig 1998; Heckscher 1995; Kanter 1989; 1993; 1995; Littleton and Arthur 2000; Yerkes 2011). Because this paper focuses on a critical case in which the new psychological contract based pursuit of employability is paramount, there is reason to doubt this assumption. A realist conception 
of employability security, or in short, employacurity, should take into account demand-side erosion of employability and a concomitant role of protection in the psychological contract.

Arthur, M. B. and D. M. Rousseau (1995), "Introduction: The boundaryless career as a new employment principle." in M. B. Arthur and D. M. Rousseau (eds) The boundaryless career: $a$ new employment principle for a new organizational era New York: Oxford University Press, pp. 3-20.

Augustsson, F. and Å. Sandberg (2004), "Time for Competence? Competence Development Among Interactive Media Workers." In C. Garsten and K. Jacobsson (eds) Learning to be employable: new agendas on work, responsibility, and learning in a globalizing world. Houndmills: Palgrave Macmillan, pp. 210-230.

Barley, S. R. and G. Kunda (2004), Gurus, Hired Guns and Warm Bodies. Itinerant Experts in a Knowledge Economy, Princeton: Princeton University Press.

Baruch, Y. (2003), "Career systems in transition. A normative model for organizational career practices." Personnel Review, 32, 2, 231-251.

Brooke, L. (2009), "Prolonging the careers of information technology workers: Continuity, exit, or retirement transitions?" Ageing \& Society, 29, 2, 237-252.

Cappelli, P.( 2001), "Why Is It So Hard to Find Information Technology Workers?" Organizational Dynamics, 30, 2, 87-99.

Castells, M. (2000), The rise of the network society. Second Edition, Malden: Blackwell.

Crouch, C. (2006), "Skill formation systems." In Ackroyd, S., Batt, R., Thompson, P. and Tolbert, P. S. (eds) The Oxford Handbook of Work and Organization, Oxford: Oxford University Press, pp. 95-114.

Gazier, B. (2001), "Employability - The Complexity of a Policy Notion." In Weinert, P., Baukens, M., Bollerot, P., Pineschi-Gapenne, M. and Walwei, U. (eds) Employability: From Theory to Practice, Somerset, NJ: Transaction Publishers, pp. 3-23.

Guest, D. E. (1998), "Is the psychological contract worth taking seriously?" Journal of Organizational Behavior 19, Special Issue: The Psychological Contract at Work, 649-994.

Ellig, B. R. (1998), "Employment and employability: foundation of the new social contract", Human Resource Management, 37, 2, 173-175.

Garsten, C. and K. Jacobsson (2004), "Learning To Be Employable: An Introduction." In C. Garsten and K. Jacobsson (eds) Learning to be employable: new agendas on work, responsibility, and learning in a globalizing world. Houndmills: Palgrave Macmillan, pp. 1-22.

Garsten, C. and K. Jacobsson (2004), "Conclusion: Discursive Transformations and the Nature of Modern Power." In C. Garsten and K. Jacobsson (eds) Learning to be employable: 
new agendas on work, responsibility, and learning in a globalizing world. Houndmills: Palgrave Macmillan, pp. 274-289.

Ghoshal, S., C. Bartlett, et al. (1999), "A new manifesto for management." Sloan Management Review 40, 3, 9-20.

Hallier, J. (2009), "Rhetoric but whose reality? The influence of employability messages on employee mobility tactics and work group identification", The International journal of human resource management, 20, 4, 846-868.

Heckscher, C. (1995), White collar blues. Management loyalties in an age of corporate restructuring. New York: Basic Books.

Hirsch, P. M. and M. Shanley (1995), "The Rhetoric of Boundaryless - Or, How the Newly Empowered Managerial Class Bought into Its Own Marginalization." In M. B. Arthur and D. M. Rousseau (eds) The boundaryless career: a new employment principle for a new organizational era. New York: Oxford University Press, pp. 218-233.

Jacobsson, K. (2004), "A European Politics for Employability: The Political Discourse on Employability of the EU and the OECD." In C. Garsten and K. Jacobsson (eds) Learning to be employable: new agendas on work, responsibility, and learning in a globalizing world. Houndmills: Palgrave Macmillan, pp. 42-61.

Kanter, R. M. (1989), "The new managerial work", Harvard Business Review, 67, 85-92.

Kanter, R. M. (1993),"The view from the 1990s: how the global economy is reshaping corporate power and careers. Afterwoord to the 1993 edition." in: R. M. Kanter, Men and Women of the Corporation. New York: Basic Books, pp. 289-328.

Kanter, R. M. (1995), "Nice Work If You Can Get It: The Software Industry as a Model for Tomorrow's Jobs. Some High-Tech Firms Are Redefining the Relationship between Employer and Employee", The American Prospect, 6, accessed at http://www.prospect.org/cs/articles?article=nice_work_if_you_can_get_it on October 28, 2009.

Latniak, E. and A. Gerlmaier (2004), "Challenges of Work Design. The Changing Role of Direct Participation." in F. Garibaldo and V. Telljohann (eds) Globalisation, Company Strategies and Quality of Working Life in Europe. Frankfurt am Main: Peter Lang, pp. 181-202.

Littleton, S. M., M. B. Arthur, et al. (2000), "The future of boundaryless careers." In A. Collin and R. A. Young (eds) The Future of Career. Cambridge: Cambridge University Press, pp. 101114.

Longenecker, C. O., C. J. Schaffer, et al. (1999), "Causes and Consequences of Stress in the IT Profession." Information Systems Management 16, 3, 71-77.

Marks, A. and T. Huzzard (2010), "Employability and the ICT worker: a study of employees in Scottish small businesses." New Technology, Work and Employment, 25, 2, 167-181 
Marks, A. and D. Scholarios (2008), "Choreographing a System: Skill and Employability in Software Work." Economic and Industrial Democracy, 29, 1, 96-124.

McMullin, J. A., T. D. Comeau and E. Jovic (2007), "Generational affinities and discourses of difference: a case study of highly skilled information technology workers." British Journal of Sociology 58, 2, 297- 316.

McQuaid, R. W. and Lindsay, C. (2005), "The Concept of Employability.", Urban Studies, 42, 2, 197-219.

Meares, C. A. and J. F. J. Sargent (1999), The Digital Work Force: Building Infotech Skills at the Speed of Innovation. Washington DC, Office of Technology Policy, http://www.eric.ed.gov/PDFS/ED441150.pdf, accessed on 24-11-2011.

Mills, C. W. (1951), White Collar, The American Middle Classes. New York, Oxford University Press. Pruijt, H. (2012) "InterviewStreamliner, a Minimalist, Free, Open Source, Relational Approach to computer-assisted Qualitative Data Analysis Software", Social Science Computer Review, 30, 2, 248-253.

Pruijt, H. and P. Dérogée (2010) “Employability and job security, friends or foes? The paradoxical reception of employacurity in the Netherlands", Socio-economic Review, 8, 3, 437-460.

Scholarios, D., Van der Heijden, B. I. J. M., Van der Schoot, E., Bozionelos, N., Epitropaki, O., Jedrzejowicz, P., Knauth, P., Marzec, I., Mikkelsen, A. and C. M. Van der Heijde (2008), "Employability and the psychological contract in European ICT sector SMEs", The International Journal of Human Resource Management, 19, 6, 1035-1055.

Schouten, E. (2006), "Sollicitant kan weer kiezen." NRC Handelblad, 5 May.

Schmid, G. (2006), "Social risk management through transitional labour markets", SocioEconomic Review, 4, 1, 1-33.

Smith, V. (2010), "Enhancing employability: Human, cultural, and social capital in an era of turbulent unpredictability." Human Relations, 63, 2, 279-300.

Svensson, L. (2004), "Lifelong Learning: A Clash Between a Production and a Learning Logic." In Garsten and K. Jacobsson (eds) Learning to be employable: new agendas on work, responsibility, and learning in a globalizing world. Houndmills, Palgrave Macmillan, pp. 83106.

Tamkin, P. and Hillage, J. (1999), Employability and Employers: the missing piece of the jigsaw, Brighton: IES

Thompson, P. (2003), "Disconnected capitalism: or why employers can't keep their side of the bargain." Work, Employment \& Society, 17: 2, 359-378.

Velzen, M. J. T. van. (2004), Learning on the fly: worker training in the age of employment flexibility. Tilburg: Universiteit van Tilburg. 
Yerkes, M. (2011), Transforming the Dutch welfare state. Social risks and corporatist reform. Bristol: The Policy Press.

\section{Acknowledgements}

I would like to thank Julie McMullin of the Workforce Ageing In The New Economy team for sharing the data that made this paper possible and for inviting me to London, Ontario and the Social Sciences Centre of the University of Western Ontario for hosting me. I am grateful to Emily Jovic for her kind assistance and to Maria Fleischmann, Pascal Dérogée and one of the anonymous reviewers for their extremely valuable comments. This work was supported by the Stichting Instituut GAK.

\footnotetext{
'For more information on the WANE project, see ww.wane.ca
} 